\title{
CHARACTERIZATION OF SLAG, FLY ASH AND PORTLAND CEMENT FOR SALTSTONE
}

J. R. Harbour, E. K. Hansen, T. B. Edwards, V. J. Williams, R. E. Eibling, D. R. Best and D. M. Missimer

February 2006 


\title{
DISCLAIMER
}

This report was prepared by Westinghouse Savannah River Company (WSRC) for the United States Department of Energy under Contract No. DE-AC09-96SR18500 and is an account of work performed under that contract. Neither the United States Department of Energy, nor WSRC, nor any of their employees makes any warranty, expressed or implied, or assumes any legal liability or responsibility for the accuracy, completeness, or usefulness, of any information, apparatus, or product or process disclosed herein or represents that its use will not infringe privately owned rights. Reference herein to any specific commercial product, process, or service by trademark, name, manufacturer or otherwise does not necessarily constitute or imply endorsement, recommendation, or favoring of same by WSRC or by the United States Government or any agency thereof. The views and opinions of the authors expressed herein do not necessarily state or reflect those of the United States Government or any agency thereof.

\author{
Printed in the United States of America \\ Prepared For \\ U.S. Department of Energy
}


Key Words: Scanning Electron Microscopy Thermogravimetric Analysis

Particle Size Distribution

\author{
Retention: Permanent
}

\title{
CHARACTERIZATION OF SLAG, FLY ASH AND PORTLAND CEMENT FOR SALTSTONE
}

J. R. Harbour, E. K. Hansen, T. B. Edwards, V. J. Williams, R. E. Eibling, D. R. Best and D. M. Missimer

February 2006

Process Science and Engineering Savannah River National Laboratory Aiken, SC 29808 


\section{REVIEWS AND APPROVALS}

\section{AUTHORS:}

J. R. Harbour, SRNL, Stabilization Science Research

Date

E. K. Hansen, SRNL, Advanced Process Development

Date

T. B. Edwards, SRNL, Statistical Consulting Section

Date

V. J. Williams, SRNL, Stabilization Science Research

Date

R. E. Eibling, SRNL, Advanced Process Development

Date

D. R. Best, SRNL, Process Engineering Technology

Date

D. M. Missimer, SRNL, Materials Characterization and Nuclear Measurement

Date

\section{TECHNICAL REVIEWERS:}

A. D. Cozzi, SRNL, Stabilization Science Research

Date

\section{APPROVERS}

D. A. Crowley, SRNL, Manager, Stabilization Science Research.

Date

C. C. Herman, SRNL, Manager, Process Engineering Technology

Date

R. E. Edwards, SRNL, Manager, Process Science and Engineering

Date

R. C. Tuckfield, SRNL, Manager, Statistical Consulting Section

Date

J. E. Occhipinti, CBU, Waste Solidification Engineering

Date

F. M. Pennebaker, Materials Characterization and Nuclear Measurement

Date 


\section{EXECUTIVE SUMMARY}

Batch-to-batch variability in the chemical and physical properties of the fly ash, slag and portland cement (binders) will be an ongoing concern over the many years that salt waste from Tank 50 will be processed into grout at the Saltstone Processing Facility. This batch-to-batch variability in the properties of the binder materials translates to variability in the fresh and cured properties of Saltstone. Therefore, it is important to quantify the batch-to-batch variability of the binder materials and the resultant variation in grout properties. This report is the starting point for that process by providing the baseline (reference point) binder properties to which future batches of binder materials can be compared.

For this characterization effort, properties of fly ash, slag and portland cement were obtained and documented in this report. These properties included particle size distribution by laser light scattering and dry sieving, particle size and morphology by scanning electron microscopy, true, aerated and tapped densities, chemical composition, rheological properties of the water based slurries made from individual binder material, and volatility through thermogravimetric analysis and differential thermal analysis.

The properties presented in this report also provide a baseline data set to assist in problem solving efforts when or if unanticipated and/or unwanted processing events occur at the Saltstone Processing Facility. 


\section{TABLE OF CONTENTS}

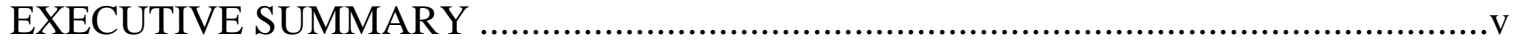

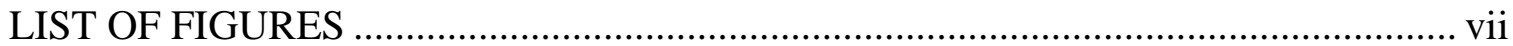

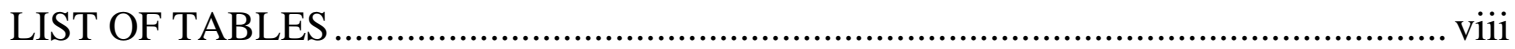

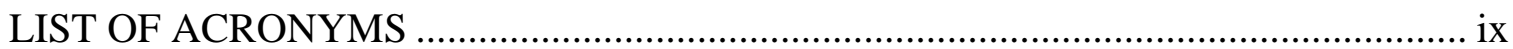

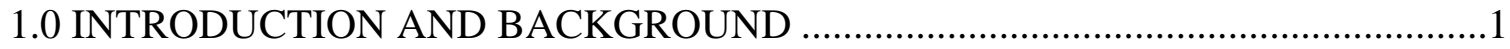

1.1 Objective of Characterization Study …………….............................................

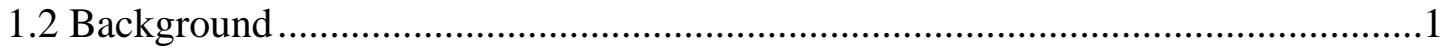

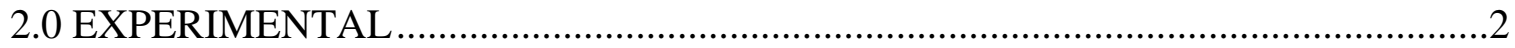

3.0 RESULTS OF THE CHARACTERIZATION STUDY .............................................

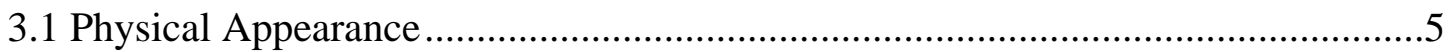

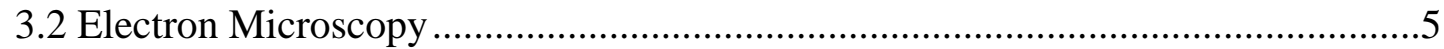

3.3 Particle Size Distribution - Laser Light Scattering ………………….......................

3.4 Particle Size Distribution - Dry Sieving..................................................................14

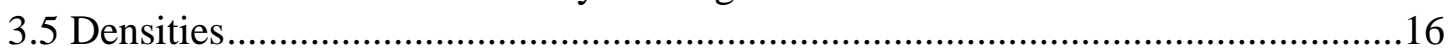

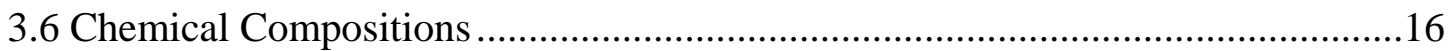

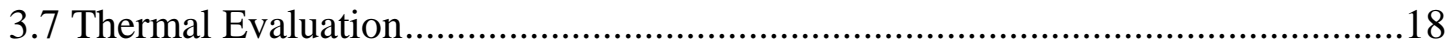

3.8 Slurry Rheology of Individual Premix Materials..................................................20

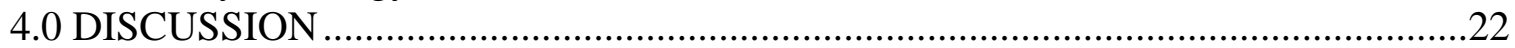

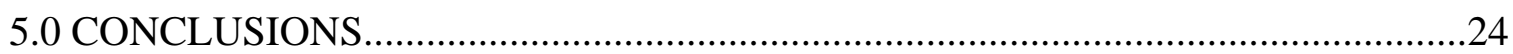

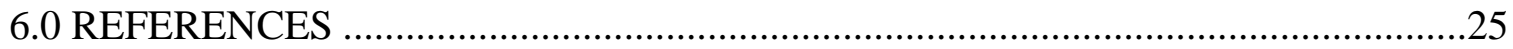




\section{LIST OF FIGURES}

Figure 2-1 ATM Sonic Sifter and Sieves............................................................................... 3

Figure 2-2 Quantachrome AT-2 Autotap............................................................................... 4

Figure 3-1 Photographs of slag, cement and fly ash obtained through the Saltstone Vendor ...... 5

Figure 3-2 SEM micrographs of blast furnace slag (Batch 2) at two different magnifications..... 6

Figure 3-3 SEM micrographs of Class F fly ash (Batch 2) at two different magnifications......... 6

Figure 3-4 SEM micrographs of portland cement (Batch 2) at two different magnifications....... 6

Figure 3-5 PSD (volume based) for Batch 1 and Batch 2 Fly Ash........................................ 8

Figure 3-6 PSD (number based) for Batch 1 and Batch 2 Fly Ash........................................... 9

Figure 3-7 PSD (volume based) for Batch 1 and Batch 2 Blast Furnace Slag ........................... 10

Figure 3-8 PSD (number based) for Batch 1 and Batch 2 blast furnace slag ............................. 11

Figure 3-9 PSD (volume based) for Batch 1 and Batch 2 Portland Cement............................... 12

Figure 3-10 PSD (number based) for Batch 1 and Batch 2 Portland Cement ............................ 13

Figure 3-11 Photograph of the fractions of portland cement captured by the filters after dry

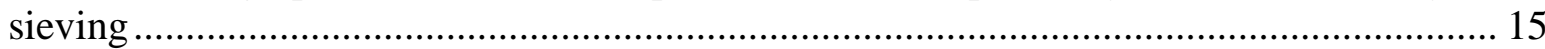

Figure 3-12 The TGA curve for Batch 2 portland cement..................................................... 18

Figure 3-13 The TGA curve for Batch 2 ground granulated blast furnace slag. ....................... 19

Figure 3-14 The TGA curve for Batch 2 fly ash.............................................................. 20 


\section{LIST OF TABLES}

Table 3-1 Mean diameters based on volume and number distributions for Batch 1 and Batch 2 slag, fly ash, and portland cement...................................................................................... 7

Table 3-2 PSDs of slag, fly ash and cement using dry sieving................................................. 14

Table 3-3 Chemical compositions of the two portland cement fractions obtained through dry

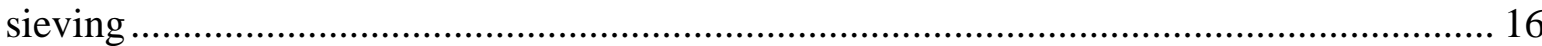

Table 3-4 Particle, aerated and tapped densities of Batch 1 and Batch 2 binder materials.......... 16

Table 3-5 Chemical compositions of the Batch 1 and Batch 2 fly ash, portland cement and slag

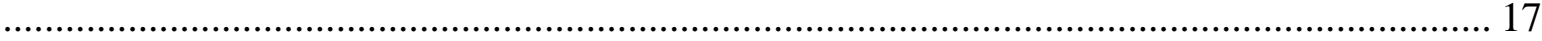

Table 3-6 Rheological data for slurries of fly ash, slag and cement in the MCU simulant.......... 21 Table 3-7 Rheological data as a function of old (Batch 1) and new (Batch 2) binder materials

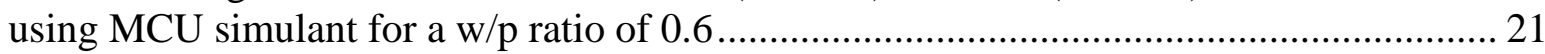




\section{LIST OF ACRONYMS}

\begin{tabular}{|l|l|}
\hline ACTL & Aiken County Technical Laboratory \\
\hline DDA & Deliquification, Dissolution and Adjustment \\
\hline DTA & Differential Thermal Analysis \\
\hline IC & Ion Chromatography \\
\hline ICPES & Inductively Coupled Plasma Emission Spectroscopy \\
\hline LOI & Loss on Ignition \\
\hline MCU & Modular Caustic Side Solvent Extraction Unit \\
\hline OPC & Ordinary Portland Cement \\
\hline PSD & Particle Size Distribution \\
\hline SEM & Scanning Electron Microscopy \\
\hline SRNL & Savannah River National Laboratory \\
\hline SRS & Savannah River Site \\
\hline TGA & Thermogravimetric Analysis \\
\hline XRD & X-Ray Diffraction \\
\hline
\end{tabular}




\subsection{INTRODUCTION AND BACKGROUND}

\subsection{Objective of Characterization Study}

The task was performed in order to characterize and document the chemical and physical properties of Type II portland cement, Class F fly ash and ground granulated blast furnace slag obtained in 2005 from the approved suppliers of these premix materials for the Saltstone Processing Facility (SPF). The objective was to provide a documented set of chemical and physical properties for each of the premix materials that can be used as the baseline properties to which all new batches of these materials can be compared.

This process provides the baseline data to (1) assess the typical batch-to-batch variability of these materials as new batches are received and (2) facilitate problem solving in the event of unexpected or undesirable processing results or conditions at Saltstone Processing Facility.

This work is part of a Technical Task Request (TTR) entitled "Scoping Studies for Development of Saltstone Variability Study” [1]. The initial report from this TTR has been issued [2].

\subsection{Background}

Specifications for fly ash, slag and portland cement (currently in revision) for use at the SPF provide a significant latitude in the acceptable range of both chemical and physical properties of these premix materials. The specifications are based mainly on ASTM Standards for blast furnace slag (ASTM C 989), class F fly ash (ASTM C 18) and portland cement (ASTM C 150).

The properties of the fly ash, slag and portland cement impact the processing and performance properties of Saltstone. From a processing perspective, the properties that are affected by the nature of the premix materials include the following:

- Flowability in the silos

- Wetting (mixing) with fluid waste stream (Tank 50) in the READCO mixer

- $\quad$ Pressure drop and flow rate in piping

- Flowability in vault

- Bleed water

- Gel Time

- Set Time

- Temperature rise

From a performance perspective, the fly ash, slag and cement impact the following properties:

- Leachability

- Redox Level

- Permeability

- Diffusivity

- Durability 


\subsection{EXPERIMENTAL}

This section details the characterization methods used for obtaining the chemical and physical properties for the fly ash, cement and slag. Two Batches of premix materials were analyzed in this study. They are referred to as Batch 1 (old) which was received in April of 2005 and Batch 2 (new) which was received in September of 2005. The work was performed at ACTL, the Process Science Analytical Laboratory, and in SRNL.

Particle Size Distribution - Laser Light Scattering. These data were obtained by the Analytical Section of Savannah River National Laboratory (SRNL) using a Microtrac S3000 particle size analyzer. In all cases, the materials were dispersed in deionized water for measurements. The reported data is an average of three separate runs.

In this type of measurement, the amount of solids in the carrier fluid is less than 0.5 weight percent to achieve sensitivity and avoidance of multiple light scattering effects. The analysis of the measured data assumes that the particles are spherical and stored in volume bins (based on micron size). The S3000 has a measuring range of 0.02 to 1408 microns. The number distribution is calculated from the volumetric distribution. This data can be presented in both volume and number distributions. The number distribution, mean volume, mean surface area and mean number are calculated from the volumetric data. The equations used to determine these values are shown in equations (2.1) and (2.2). If the densities of the solids are the same for all particle sizes, then the volume distribution can be treated as a mass distribution.

$$
\begin{aligned}
& {\left[\begin{array}{l}
n_{i}=\frac{6 \cdot V_{i}}{\pi \cdot d_{i}^{3}} \\
N_{i}=\frac{n_{i}}{\sum n_{i}} \times 100 \%
\end{array}\right]} \\
& {\left[\begin{array}{l}
\text { mv(mean volume })=\frac{\sum V_{i} d_{i}}{\sum V_{i}} \\
\text { ma(mean surface area })=\frac{\sum V_{i}}{\sum\left(V_{i} / d_{i}\right)} \\
m n(\text { mean number })=\frac{\sum\left(V_{i} / d_{i}^{2}\right)}{\sum\left(V_{i} / d_{i}^{3}\right)}
\end{array}\right]}
\end{aligned}
$$

where: $\mathrm{V}_{\mathrm{i}}=$ volume $\%$ in the $\mathrm{i}^{\text {th }}$ bin

$\mathrm{d}_{\mathrm{i}}=$ average bin diameter

$\mathrm{n}_{\mathrm{i}}=$ number of particles in the $\mathrm{i}^{\text {th }}$ bin, given volume $\%$

$\mathrm{N}_{\mathrm{i}}=$ number $\%$ in the $\mathrm{i}^{\text {th }}$ bin (data normalized) 
Particle Size Distribution - Dry Sieving. These measurements were performed using an ATM Sonic Sifter which utilizes sieves that comply with ASTM standards. Approximately two grams of material were placed on the top of the largest sized sieve and the instrument operated for five minutes. In all cases the instrument was run in the sift/pulse mode with a pulse amplitude setting of seven. The Sonic Sifter and the associated sequence of sieves, spacers and collectors used are shown in Figure 2-1.

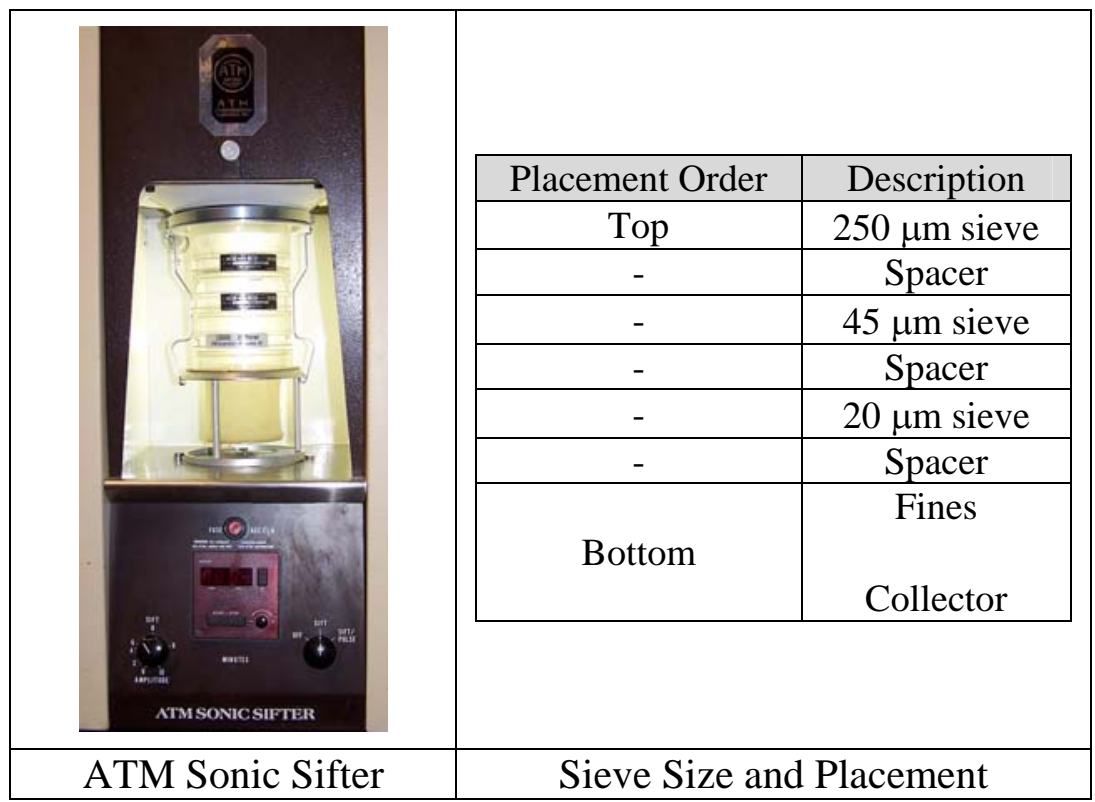

Figure 2-1 ATM Sonic Sifter and Sieves

Bulk and Tapped Powder Densities. The aerated and tapped densities were obtained using a Quantachrome AT-2 Autotap shown in Figure 2-2. ASTM B527 describes the use of graduated cylinders and the number of taps to obtain the tapped density. In this task, a $100 \mathrm{~mL}$ graduated cylinder and 2000 taps were used. Approximately $80 \mathrm{~mL}$ of material was added to the graduated cylinder, the cylinder covered with a piece of Parafilm, and the cylinder gently rocked back and forth to aerate the powder. The initial volume and mass were recorded. The graduated cylinder was then installed onto the AT-2 and processed. The final volume was then recorded. The tapped density for each material was determined by dividing the mass by the tapped volume. 


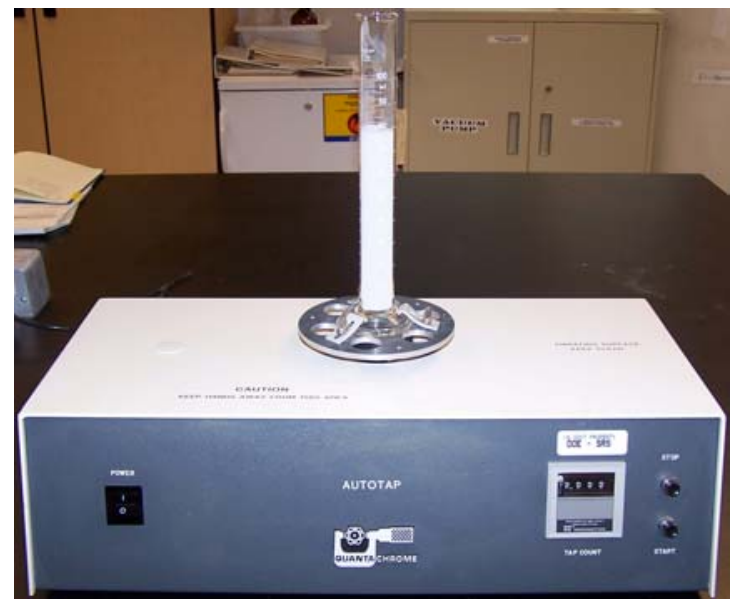

Figure 2-2 Quantachrome AT-2 Autotap

Thermal Evaluation. A Netzsch STA 409 PC thermal analyzer was used to measure the mass change with temperature (TGA) and the differential thermal analysis up to $1200{ }^{\circ} \mathrm{C}$.

Rheology. A Haake RS600 or RS150 rheometer was used to obtain the flow curve for each of the slurries. After mixing was complete, a sample was poured directly from the mix vessel into the rheology cup and sent for rheology. The flow curve covered the shear rate range from 0 to $300 \mathrm{sec}^{-1}$ at a measurement temperature of $25^{\circ} \mathrm{C}$.

The details of the rheological measurements are provided in a report by Hansen and Langton [3].

Chemical Composition. These measurements were made at the Process Science Analytical Laboratory and involved dissolution of the powders and subsequent analysis by Ion Chromatography (IC) and Inductively Coupled Plasma Emission Spectroscopy (ICPES). 


\subsection{RESULTS OF THE CHARACTERIZATION STUDY}

This section presents the results of the physical and chemical characterization and analyses of fly ash, portland cement and blast furnace slag.

\subsection{Physical Appearance}

The physical appearance of each of the materials provides a visual baseline to which future batches may be compared. Figure 3-1 provides a side-by-side comparison of the three Saltstone binder materials, slag, portland cement and fly ash. The blast furnace slag is a dull white color while portland cement and fly ash are gray colored. Portland cement particles are a darker gray than the fly ash powder.

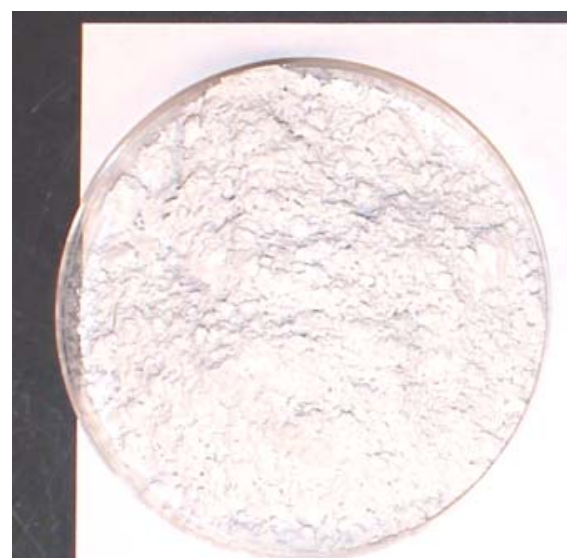

Blast Furnace Slag

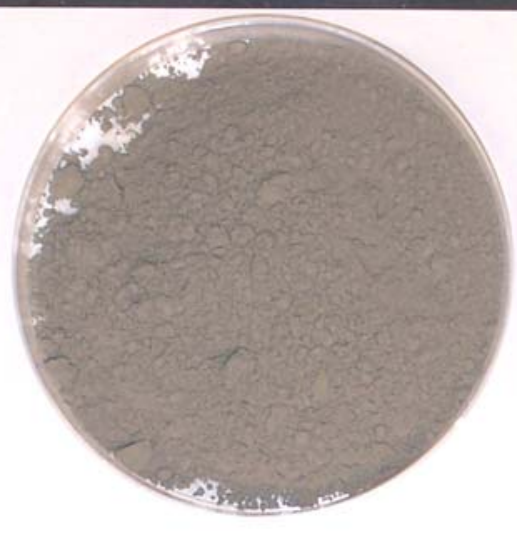

Portland Cement

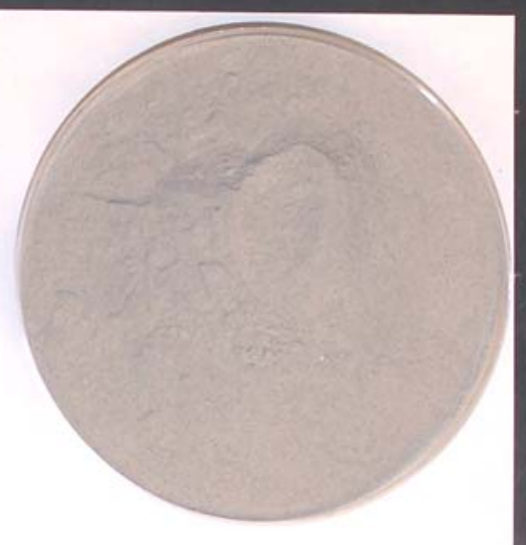

Class F Fly Ash

Figure 3-1 Photographs of slag, cement and fly ash obtained through the Saltstone Vendor

\subsection{Electron Microscopy}

The SEM micrographs for the binder materials are presented in Figures 3-2, 3-3 and 3-4. Both the slag and portland cement are products of grinding and therefore are irregular in shape and look somewhat alike in the micrographs (Figures 3-2 and 3-4). The fly ash, on the other hand, is formed in the combustion process at the coal burning power plant which generates mainly spherical particles. All the micrographs show that many small particles ( $<1$ micron) are present in all the powders. 

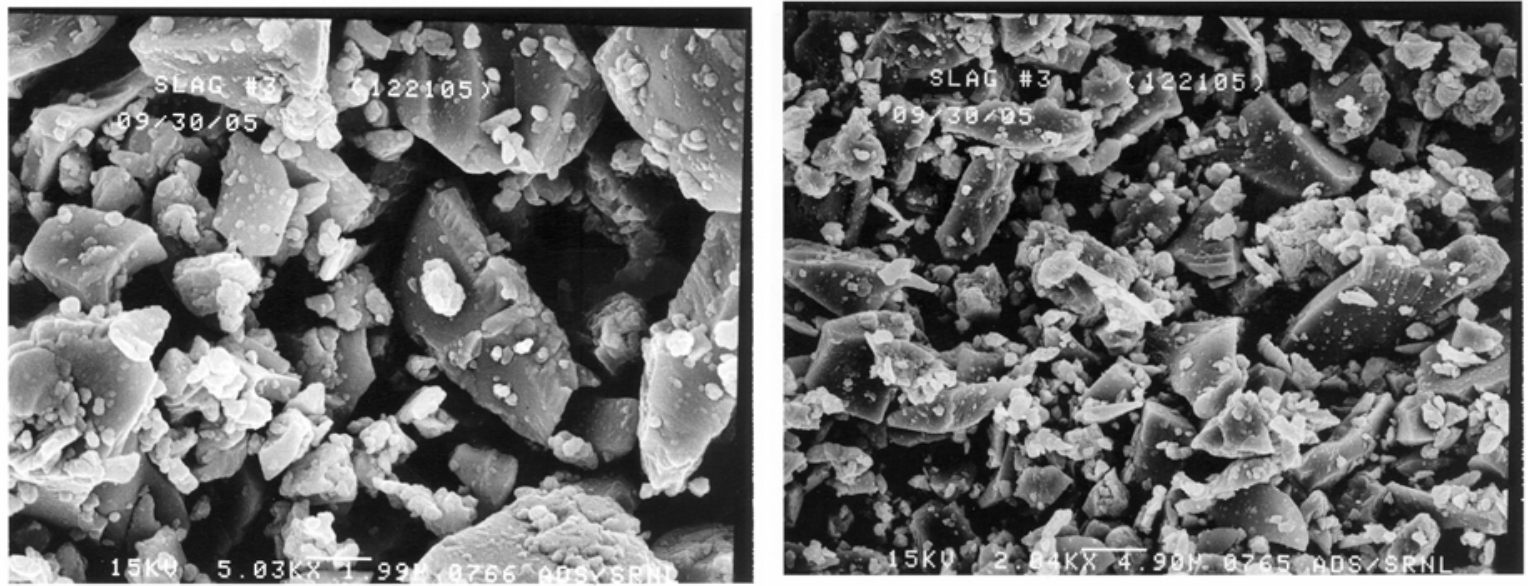

Figure 3-2 SEM micrographs of blast furnace slag (Batch 2) at two different magnifications.
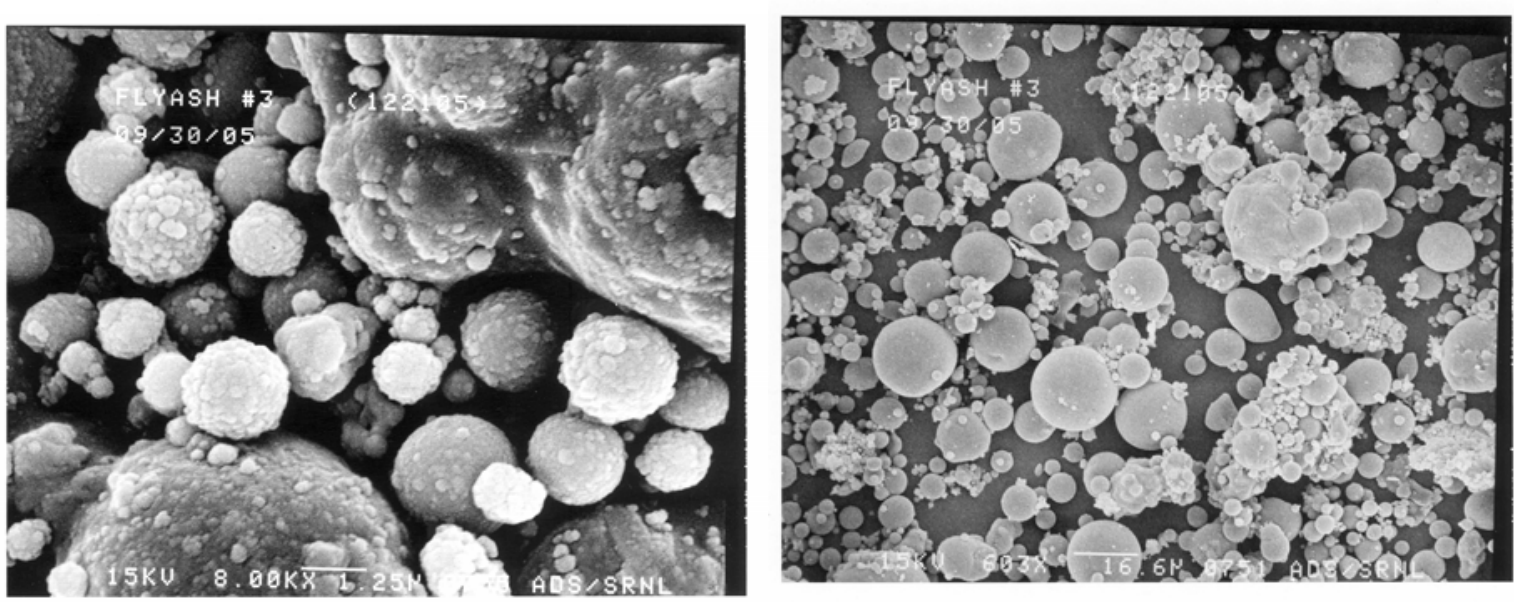

Figure 3-3 SEM micrographs of Class F fly ash (Batch 2) at two different magnifications.
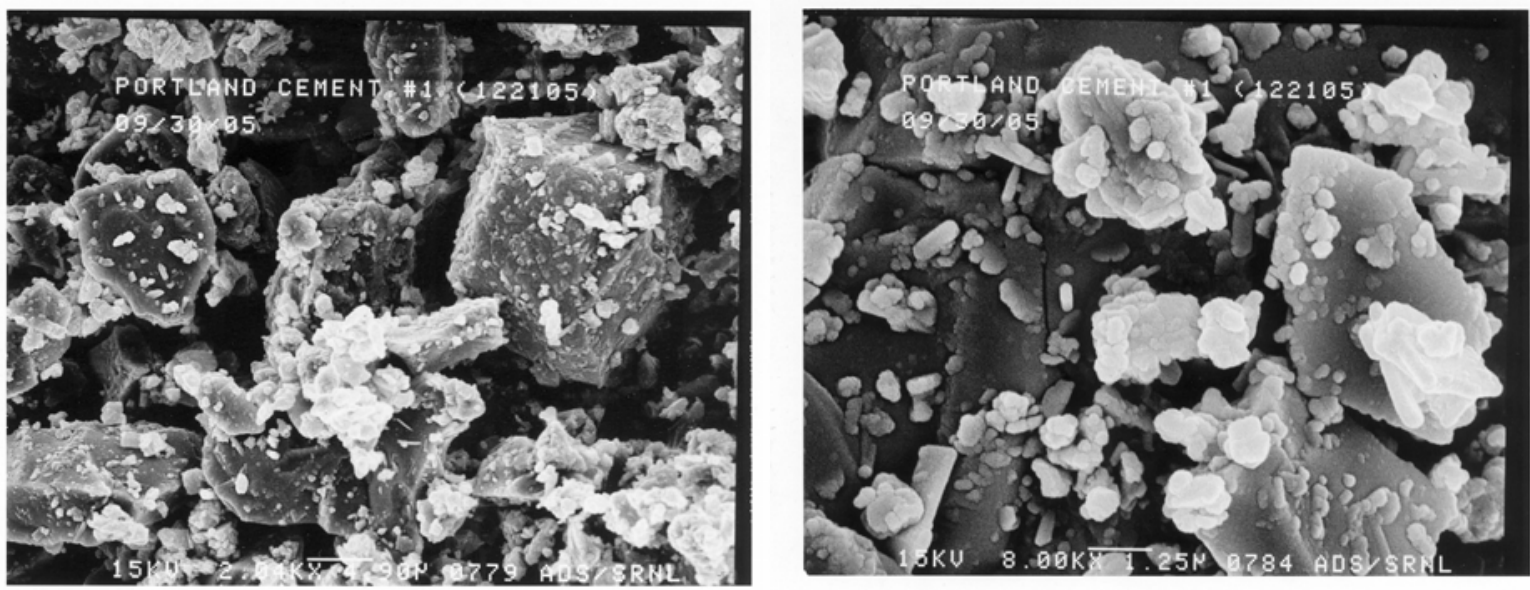

Figure 3-4 SEM micrographs of portland cement (Batch 2) at two different magnifications. 


\subsection{Particle Size Distribution - Laser Light Scattering}

The particle size distributions (PSDs) of the premix powders in deionized water were obtained by laser light scattering. Due to the hydraulic nature of portland cement, these materials were placed into the deionized water, dispersed and then immediately measured. Organic solvent carrier fluids have been used by others (outside SRNL) to disperse the portland cement. However, the resulting PSDs obtained using deionized water as the carrier fluid are typical of literature values. The mean diameter volume, medium diameter volume and mean diameter number are summarized in Table 3-1.

Table 3-1 Mean diameters based on volume and number distributions for Batch 1 and Batch 2 slag, fly ash, and portland cement.

\begin{tabular}{|c|c|c|c|c|c|}
\hline \multicolumn{2}{|c|}{ Material } & \multicolumn{2}{c|}{ Volume Diameter (microns) } & \multicolumn{2}{c|}{ Number Diameter (microns) } \\
\cline { 3 - 6 } & Batch 1 & 8.80 & 6.74 & 0.63 & 0.52 \\
\cline { 2 - 6 } Slag & Batch 2 & 9.10 & 7.83 & 0.73 & 0.58 \\
\hline \multirow{2}{*}{ Fly Ash } & Batch 1 & 47.60 & 30.2 & 0.67 & 0.53 \\
\cline { 2 - 6 } & Batch 2 & 37.70 & 29.5 & 0.68 & 0.54 \\
\hline \multirow{2}{*}{ Portland Cement } & Batch 1 & 22.00 & 19.0 & 0.66 & 0.46 \\
\cline { 2 - 6 } & Batch 2 & 24.90 & 20.5 & 0.59 & 0.47 \\
\hline
\end{tabular}

The particle size distributions (PSD) on both a volume and number basis are presented in Figures 3-5 through 3-10 for fly ash, slag and portland cement.

These results indicate that many fine particles ( $<1$ micron) are present in all three powders. However, these smaller particles contribute little to the overall mass and volume of the powders. This results in a significant difference between the volume distribution and the number distribution consistent with equations (2.1) and (2.2). The fly ash has the highest percentage of large particles whereas the slag has the lowest percentage of large particles. 


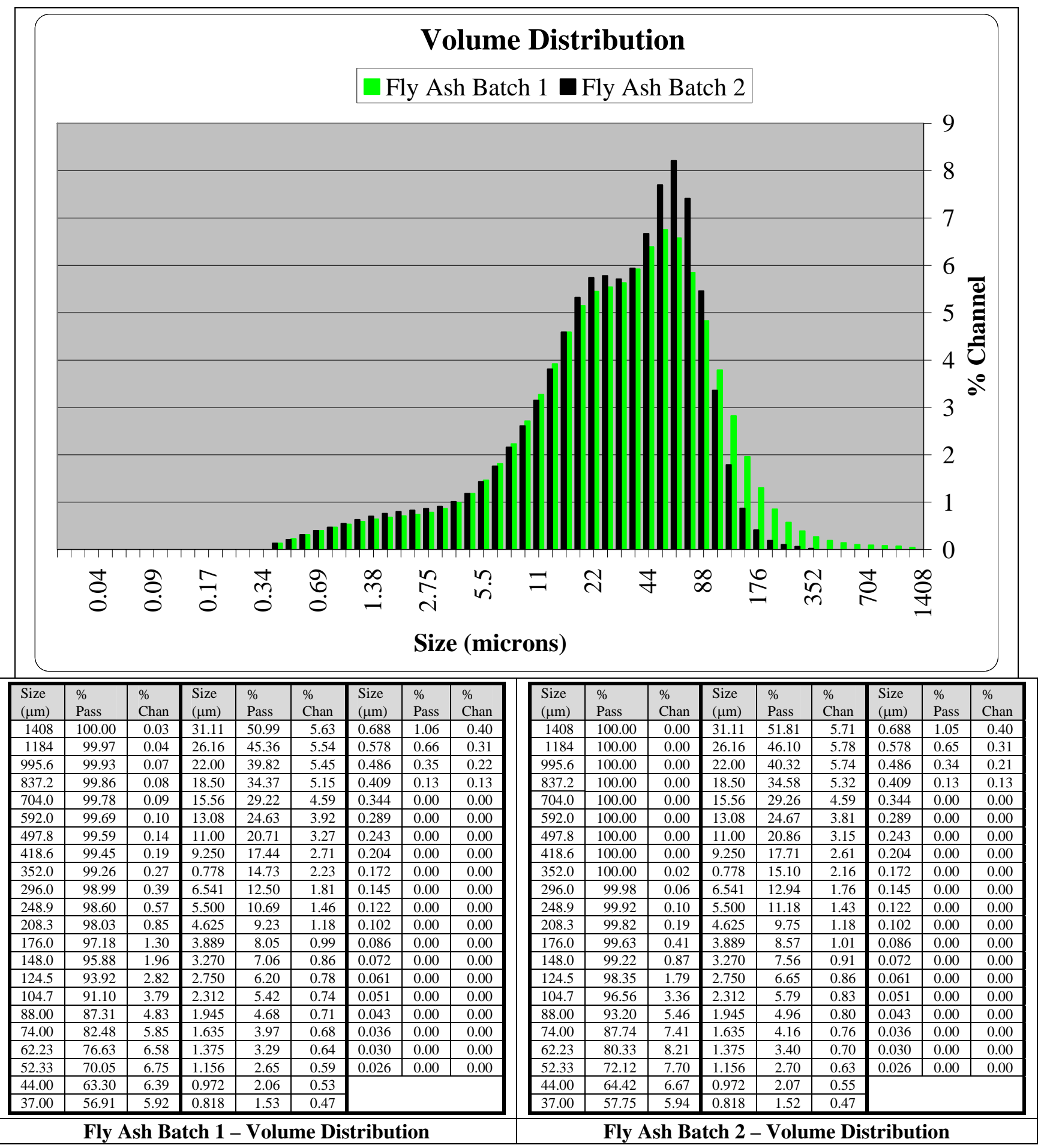

Figure 3-5 PSD (volume based) for Batch 1 and Batch 2 Fly Ash 


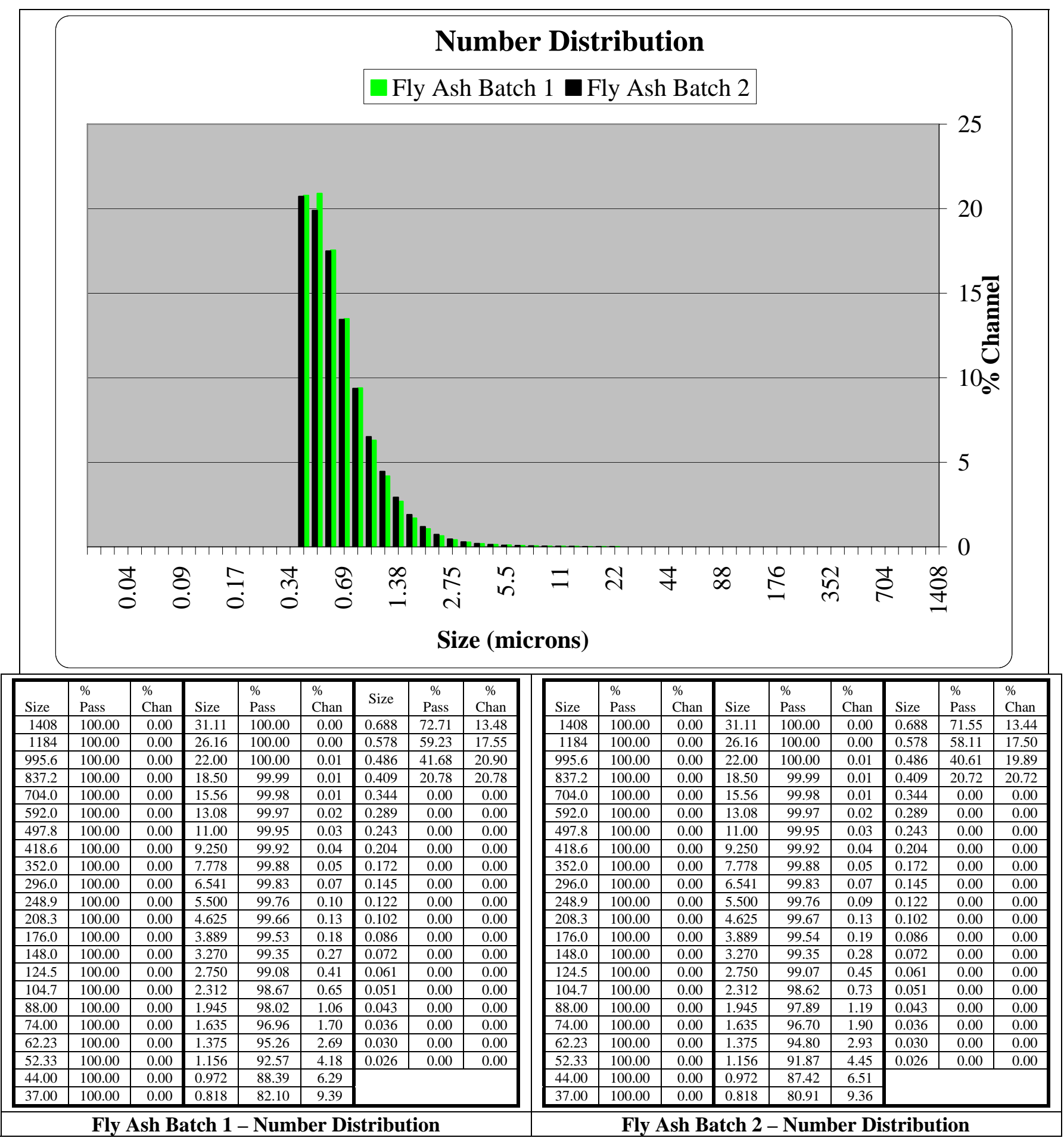

Figure 3-6 PSD (number based) for Batch 1 and Batch 2 Fly Ash 


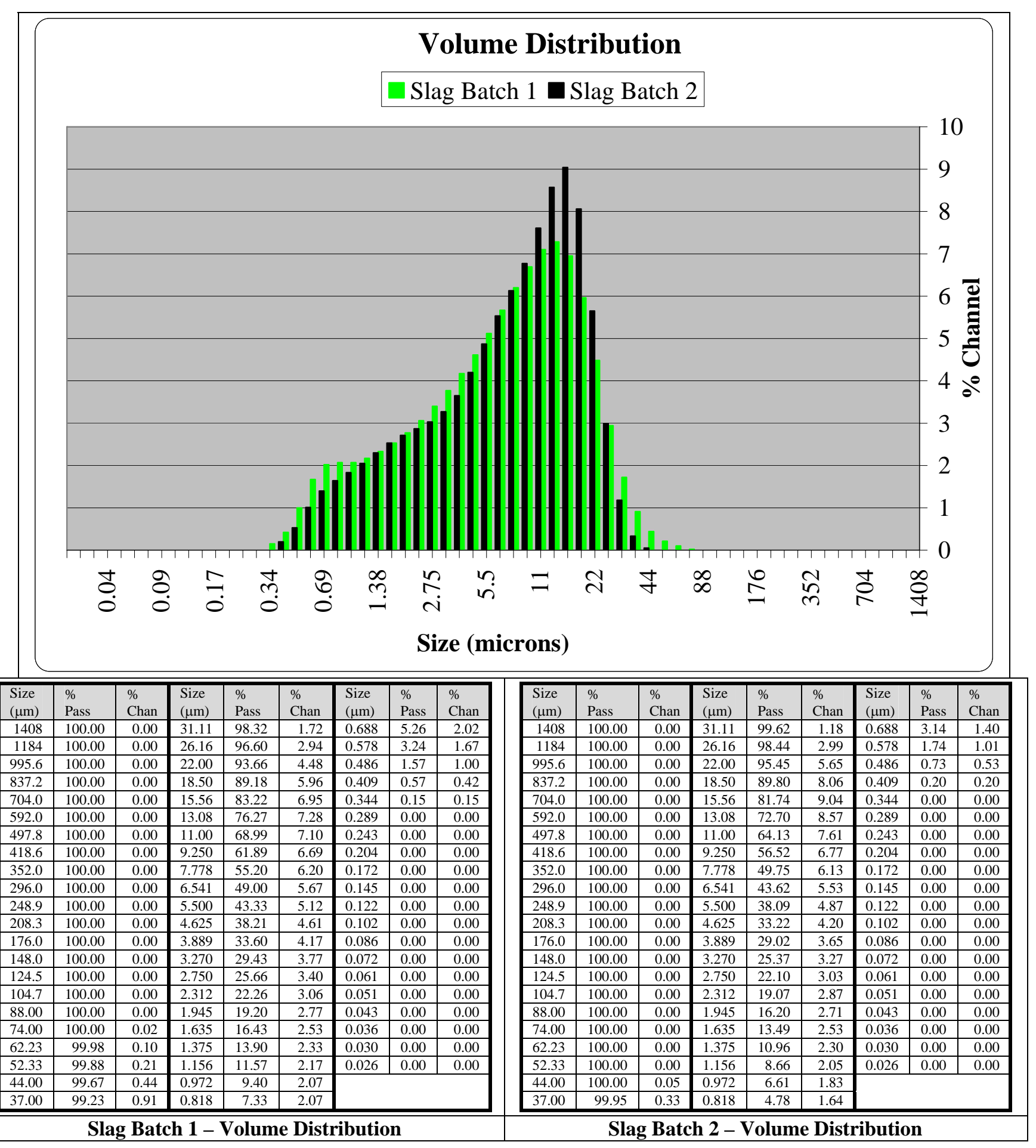

Figure 3-7 PSD (volume based) for Batch 1 and Batch 2 Blast Furnace Slag 
WSRC-TR-2006-00067

Revision 0

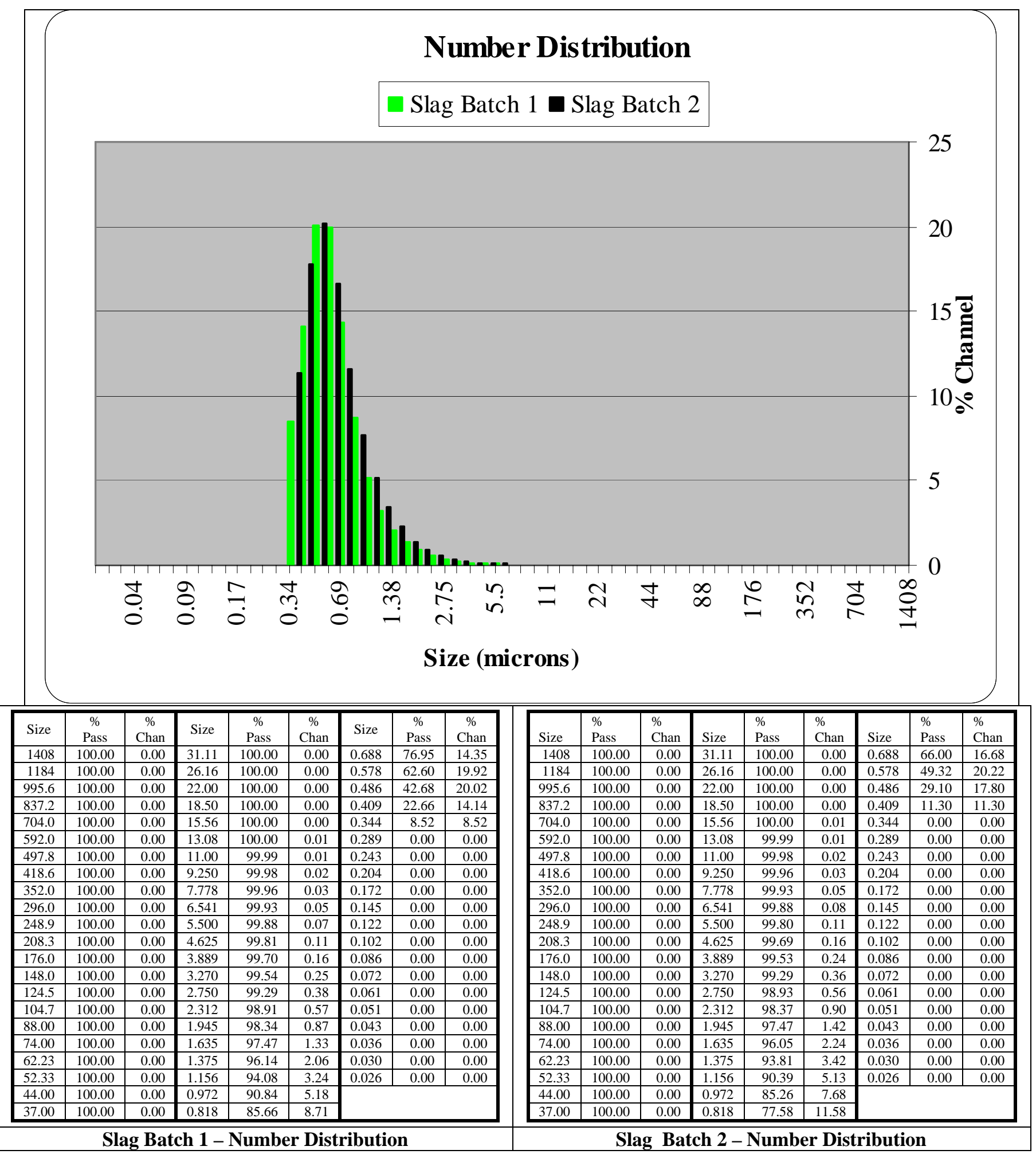

Figure 3-8 PSD (number based) for Batch 1 and Batch 2 blast furnace slag 


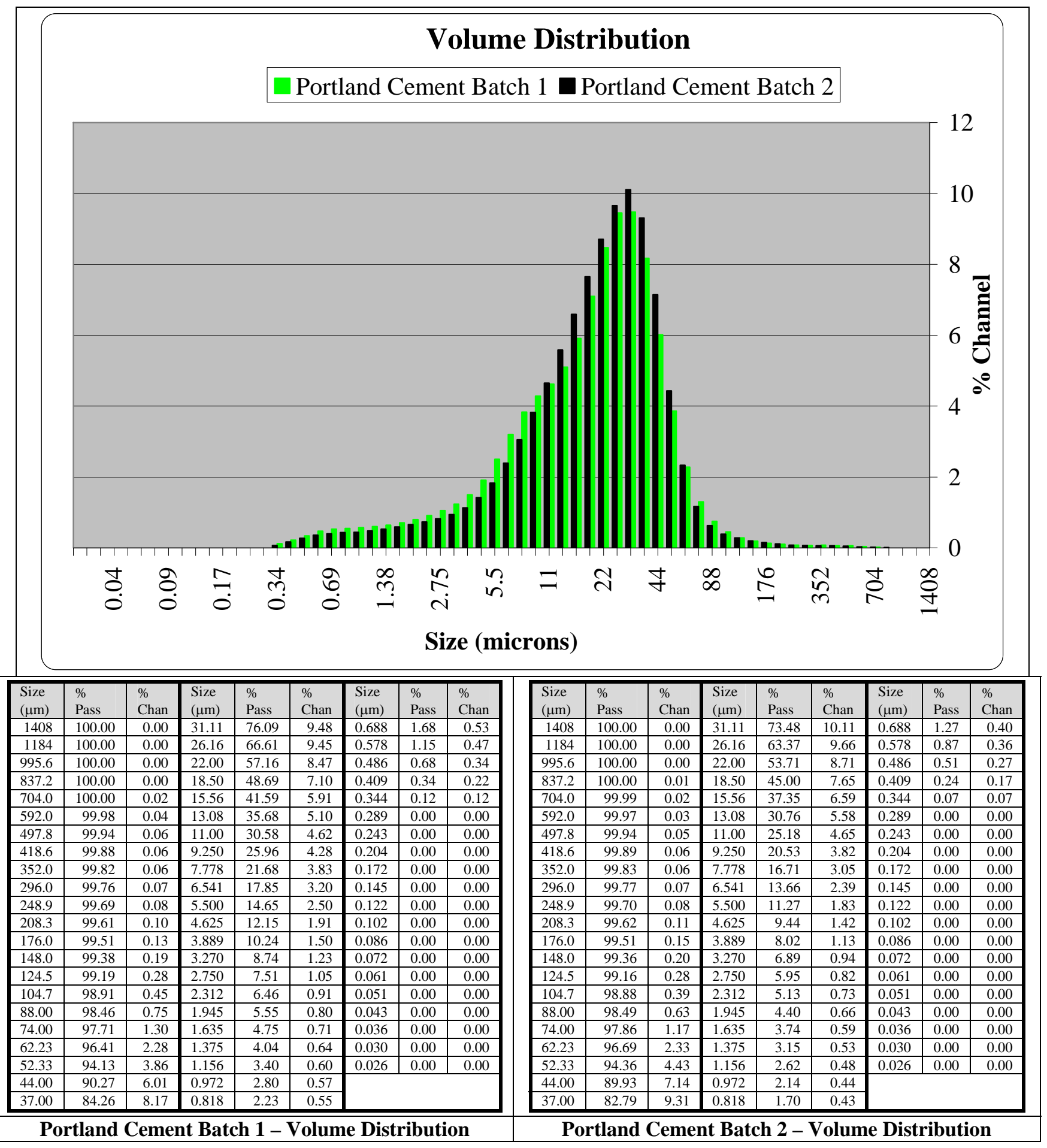

Figure 3-9 PSD (volume based) for Batch 1 and Batch 2 Portland Cement. 
WSRC-TR-2006-00067

Revision 0

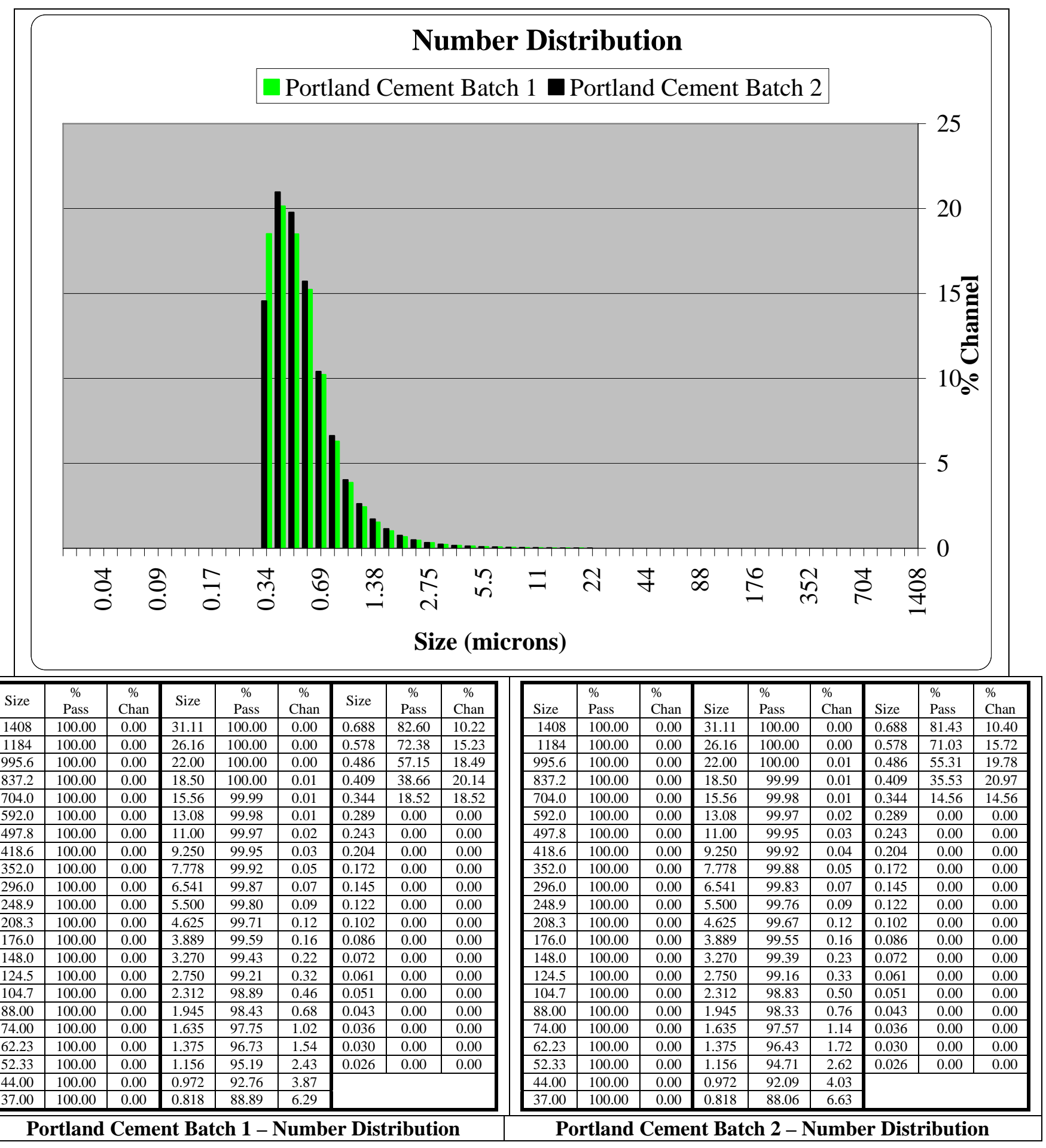

Figure 3-10 PSD (number based) for Batch 1 and Batch 2 Portland Cement 


\subsection{Particle Size Distribution - Dry Sieving}

The results from dry sieving of the premix materials are provided in Table 3-2.

Table 3-2 PSDs of slag, fly ash and cement using dry sieving

\begin{tabular}{|c|c|c|c|c|c|c|}
\hline \multirow{3}{*}{ Material } & \multicolumn{3}{|c|}{ Batch 1} & \multicolumn{3}{|c|}{ Batch 2} \\
\hline & \multirow{2}{*}{ Size (microns) } & \multicolumn{2}{|c|}{ Weight Percent of Material } & \multirow{2}{*}{ Size (microns) } & \multicolumn{2}{|c|}{ Weight Percent of Material } \\
\hline & & Run \#1 & Run \#2 & & Run \#1 & Run \#2 \\
\hline \multirow{5}{*}{$\frac{\vec{\pi}}{\vec{N}}$} & $x \geq 250$ & 26.20 & 27.88 & $x \geq 250$ & 4.01 & 2.73 \\
\hline & $250>x \geq 45$ & 42.26 & 43.76 & $250>x \geq 45$ & 36.83 & 37.49 \\
\hline & $45>x \geq 20$ & 26.06 & 22.78 & $45>x \geq 20$ & 32.19 & 37.10 \\
\hline & $20>x$ & 4.42 & 4.91 & $20>x$ & 22.86 & 23.07 \\
\hline & TOTALS & 98.93 & 99.33 & TOTALS & 95.89 & 100.40 \\
\hline \multirow{5}{*}{$\begin{array}{l}\frac{\pi}{5} \\
\frac{\pi}{\Delta} \\
\frac{\lambda}{I}\end{array}$} & $x \geq 250$ & 1.38 & 0.93 & $x \geq 250$ & 0.69 & 1.38 \\
\hline & $250>x \geq 45$ & 35.01 & 34.21 & $250>x \geq 45$ & 35.08 & 34.59 \\
\hline & $45>x \geq 20$ & 44.82 & 52.05 & $45>x \geq 20$ & 33.33 & 31.45 \\
\hline & $20>x$ & 18.29 & 12.77 & $20>x$ & 29.57 & 31.99 \\
\hline & TOTALS & 99.51 & 99.95 & TOTALS & 98.67 & 99.41 \\
\hline \multirow{5}{*}{ 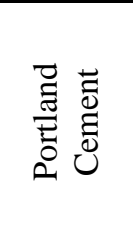 } & $x \geq 250$ & 4.42 & 6.37 & $x \geq 250$ & 30.36 & 29.68 \\
\hline & $250>x \geq 45$ & 19.97 & 22.35 & $250>x \geq 45$ & 7.42 & 5.60 \\
\hline & $45>x \geq 20$ & 25.11 & 23.55 & $45>x \geq 20$ & 18.75 & 19.03 \\
\hline & $20>x$ & 50.07 & 47.35 & $20>x$ & 43.28 & 42.92 \\
\hline & TOTALS & 99.57 & 99.61 & TOTALS & 99.81 & 97.23 \\
\hline
\end{tabular}

These results reflect a problem with dry sieving that is well-known. That is, the particles of some of the materials were either pre-agglomerated or became agglomerated during the sieving process and consequently do not pass through the sieves. Therefore, there were significant differences in the amount of material retained by the 250 micron sieve for the two batches of slag and Ordinary Portland Cement (OPC). This was not observed for fly ash.

Additional samples of slag and cement from both batches were obtained from different bottles and characterized using the ATM sonic sifter (the original raw materials were subdivided when received by placing them in 2-liter bottles that were then sealed). The results reconfirmed that Batch 1 of the slag and Batch 2 of the OPC have a much higher quantity of particles in the 250 micron sieve than Batch 2 of the slag and Batch 1 of the OPC (there is, however, some scatter in the results). The general reproducibility of this measurement demonstrates that there are differences in the two batches that affect their tendency to agglomerate. The agglomerates present on top of the 250 micron sieve were readily dispersed into smaller particles using a spatula. Agglomerates were also evident on the 45 micron sieve.

This method provides a visualization of the different fractions of the particle size for the premix materials which in turn can lead to the detection of extraneous or unexpected materials. For example, the Batch 2 fly ash had black particles present in both the 250 and the 45 micron 
screens. Placing a magnet close to the top surface of the sieves resulted in a transfer of the magnetic particles to the pole of the magnet and the formation of magnetic alignment of these particles on the pole surface. Placement of the magnet on the underside of the sieves allowed the magnetic particles to be moved about on the top surface of the sieves. Batch 1 fly ash had significantly less magnetic material as compared to Batch 2 fly ash. In both cases there were some black particles that were not attracted to the magnet.

With the portland cement, one of the fractions had a different color than the other three fractions. The fractions captured on the 250 and 45 micron sieves were light gray in color whereas the particles on the 20 micron sieve were darker in appearance. The fines, which had passed through the 20 micron sieve, were again light gray (see Figure 3-11). The chemical compositions of the light gray fines and the darker 20 to 45 micron fraction were measured and are presented in Table 3.3. The changes are relatively minor with the largest mass changes occurring with calcium oxide and sulfate.

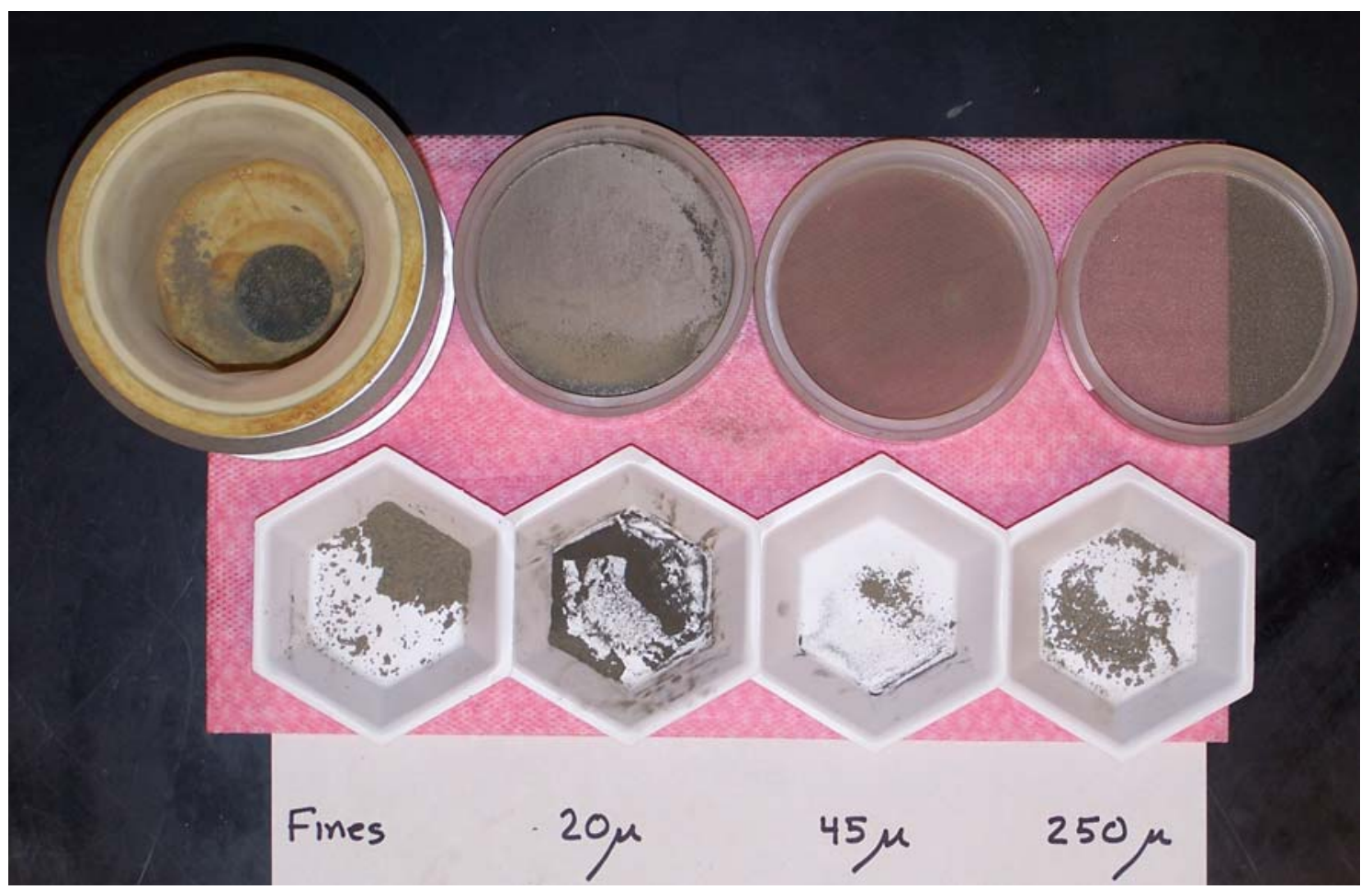

Figure 3-11 Photograph of the fractions of portland cement captured by the filters after dry sieving 
Table 3-3 Chemical compositions of the two portland cement fractions obtained through dry sieving

\begin{tabular}{|c|c|c|c|c|c|c|c|c|c|}
\hline \multirow{2}{*}{ Size } & \multicolumn{9}{|c|}{ Oxides (Percentage) } \\
\cline { 2 - 10 } & $\mathrm{Al}_{2} \mathrm{O}_{3}$ & $\mathrm{CaO}$ & $\mathrm{Fe}_{2} \mathrm{O}$ & $\mathrm{K}_{2} \mathrm{O}$ & $\mathrm{MgO}$ & $\mathrm{Na}_{2} \mathrm{O}$ & $\mathrm{P}_{2} \mathrm{O}_{5}$ & $\mathrm{SO}_{4}$ & $\mathrm{SiO}_{2}$ \\
\hline $\mathrm{x}<20 \mu \mathrm{m}$ & 5.37 & 64.61 & 3.51 & 0.62 & 1.21 & 0.15 & 0.24 & 3.2 & 20.36 \\
\hline $20 \mu \mathrm{m} \leq \mathrm{x}<45 \mu \mathrm{m}$ & 5.43 & 67.06 & 3.32 & 0.44 & 1.23 & 0.13 & 0.25 & 2.07 & 20.09 \\
\hline Absolute Difference & -0.06 & -2.45 & 0.19 & 0.18 & -0.02 & 0.02 & 0.01 & 1.13 & 0.27 \\
\hline \hline \% Difference $(<20 \mathrm{~mm})$ & -1.12 & -3.79 & 5.41 & 29.03 & -1.65 & 13.33 & 4.17 & 35.31 & 1.33 \\
\hline
\end{tabular}

\subsection{Densities}

Densities of the binder materials provide another means of characterization of the slag, cement and fly ash. In this case the densities were determined for the dry particles. Although particle (true) densities for the binder materials were not measured, typical values were obtained from the literature and included in Table 3-4.

The aerated and tapped densities were measured for slag, cement and fly ash. Tapping deaerates the powder, allowing the particles to compact within the graduated cylinder to produce a greater density than that measured for the aerated materials. The ratio of the two densities (tapped/aerated) is the Hausner Ratio, which provides an indication of the degree of compaction that a dry powder can undergo in handling and storage. The fly ash batches are significantly different. The fly ash tapped density of Batch 2 is much larger than that of Batch 1 . The tapped densities of the slag and cement are more consistent for Batch 1 and Batch 2. The aerated densities have more variability, because the preparation of the materials may not aerate the materials consistently.

Table 3-4 Particle, aerated and tapped densities of Batch 1 and Batch 2 binder materials.

\begin{tabular}{||c|c|c|c|c|c||}
\hline \multirow{2}{*}{ Material } & \multirow{2}{*}{ Batch \# } & \multicolumn{3}{|c|}{ Densities $\left(\mathrm{g} / \mathrm{cm}^{3}\right)$} & \multirow{2}{*}{$\begin{array}{c}\text { Hausner } \\
\text { Ratio }\end{array}$} \\
\cline { 3 - 6 } & & Particle Density* & Aerated Density & Tapped Density & 1.37 \\
\hline \multirow{2}{*}{ Class F Fly Ash } & 1 & 2.26 & 0.92 & 1.26 & 1.46 \\
\cline { 2 - 6 } & 2 & 2.26 & 1.02 & 1.49 & 1.56 \\
\hline \multirow{2}{*}{ Blast Furnace Slag } & 1 & 2.75 & 0.81 & 1.26 & 1.59 \\
\cline { 2 - 6 } & 2 & 2.75 & 0.80 & 1.27 & 1.63 \\
\hline \multirow{2}{*}{ Portland Cement } & 1 & 3.07 & 0.90 & 1.46 & 1.45 \\
\cline { 2 - 6 } & 2 & 3.07 & 1.00 & 1.45 & \\
\hline
\end{tabular}

*See e.g., Cement Chemistry by H. F. W. Taylor [5]

\subsection{Chemical Compositions}

The chemical compositions of the fly ash, cement and slag for both batches are presented in Table 3-5. These data, obtained from both ICPES and IC can be used as the basis for comparison with future batches of these materials. Carbon is an important volatile from fly ash 
and therefore, a volatiles contribution from carbon was added to the overall sum of oxides for fly ash (See Section 3.7).

Table 3-5 Chemical compositions of the Batch 1 and Batch 2 fly ash, portland cement and slag

\begin{tabular}{|c|c|c|c|c|c|c|}
\hline \multirow{2}{*}{ Oxide } & \multicolumn{2}{|c|}{ Fly Ash } & \multicolumn{2}{c|}{ Portland Cement } & \multicolumn{2}{c|}{ Slag } \\
\cline { 2 - 7 } & Batch 1 & Batch 2 & Batch 1 & Batch 2 & Batch 1 & Batch 2 \\
\hline $\mathrm{Al}_{2} \mathrm{O}_{3}$ & 28.6 & 28.6 & 5.4 & 5.2 & 8.4 & 6.6 \\
\hline $\mathrm{CaO}$ & 0.7 & 0.6 & 64.9 & 63.0 & 38.5 & 35.0 \\
\hline $\mathrm{Fe}_{2} \mathrm{O}_{3}$ & 6.0 & 5.6 & 3.7 & 3.8 & 0.4 & 0.3 \\
\hline $\mathrm{K}_{2} \mathrm{O}$ & 2.6 & 2.5 & 0.5 & 0.7 & 0.3 & 0.5 \\
\hline $\mathrm{MgO}$ & 0.9 & 0.8 & 1.2 & 1.2 & 12.9 & 13.1 \\
\hline $\mathrm{Na}_{2} \mathrm{O}$ & 0.3 & 0.4 & 0.1 & 0.2 & 0.3 & 0.3 \\
\hline $\mathrm{SO}_{4}$ & 0.1 & 0.3 & 3.2 & 3.3 & 1.0 & 2.5 \\
\hline $\mathrm{SiO}_{2}$ & 54.2 & 56.8 & 20.5 & 20.3 & 37.9 & 40.4 \\
\hline $\mathrm{TiO}_{2}$ & 1.6 & 1.4 & 0.3 & 0.3 & 0.4 & 0.3 \\
\hline $\mathrm{Volatiles}^{2}$ & 2.5 & 1.4 & 0.0 & 0.0 & 0.0 & 0.0 \\
\hline Total & $\mathbf{9 7 . 5}$ & $\mathbf{9 8 . 4}$ & $\mathbf{9 9 . 8}$ & $\mathbf{9 8 . 0}$ & $\mathbf{1 0 0 . 1}$ & $\mathbf{9 9 . 0}$ \\
\hline
\end{tabular}




\subsection{Thermal Evaluation}

Thermogravimetric analysis detects not only the change in mass of a material as a function of temperature but also identifies the temperature ranges over which significant mass changes occur. This information can be useful as a fingerprint for the identification of each of the premix materials. The outputs can therefore be used to compare batch-to-batch variation in the slag, cement and fly ash. The ASTM Standards for premix materials also have limits on volatility of these materials. In particular, water content and carbon, both of which can affect the properties of Saltstone, are limited by the ASTM Standards.

The portland cement displayed a series of mass losses as shown in Figure 3.12. There were differences in the magnitude of these changes between Batch 1 and 2 but the overall profiles were equivalent. Mass loss for Batch 1 portland cement was $\sim 1 \mathrm{wt} \%$ while Batch 2 had a mass loss of $~ 1.5 \mathrm{wt} \%$.

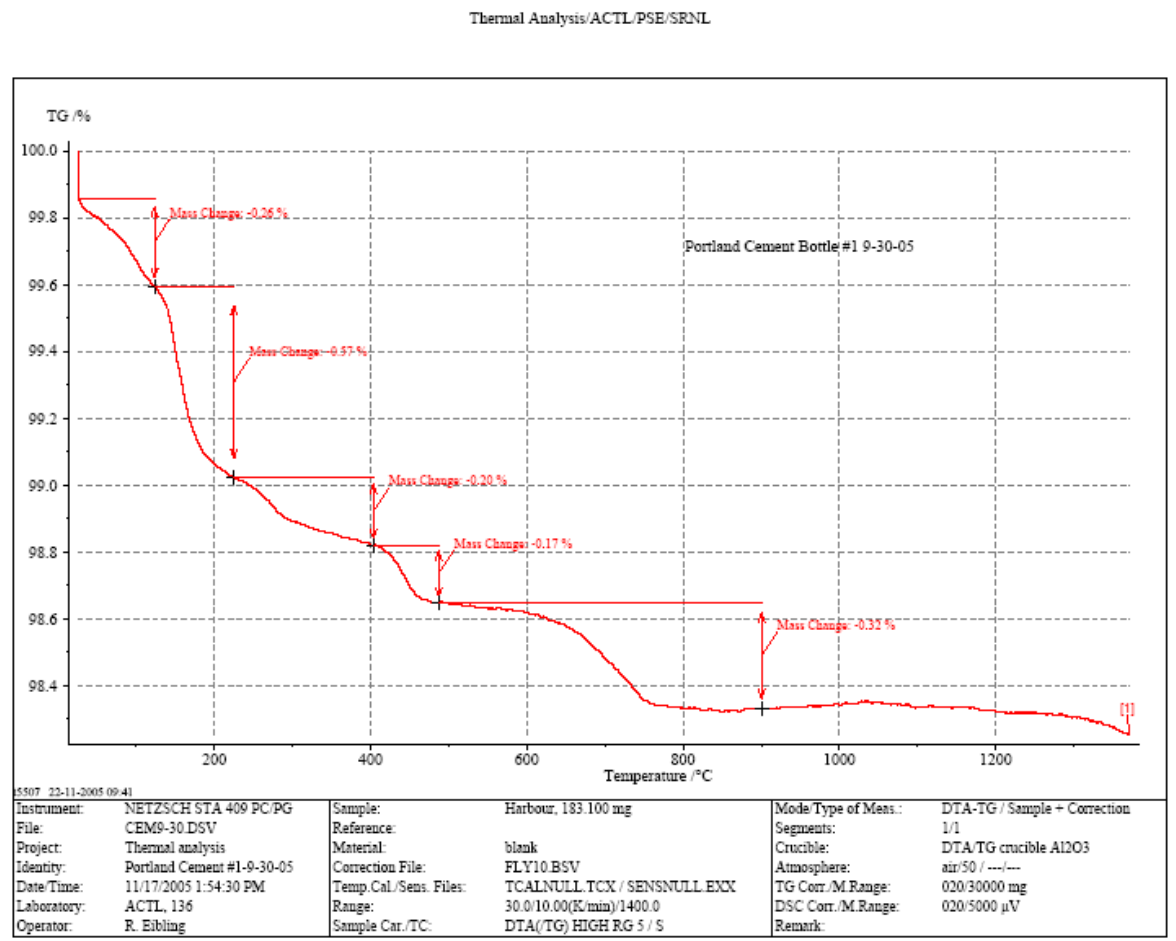

Figure 3-12 The TGA curve for Batch 2 portland cement.

The ground granulated blast furnace slag exhibited a weight loss up to $700{ }^{\circ} \mathrm{C}$ and then went through a weight gain that peaked at $1100{ }^{\circ} \mathrm{C}$. Over the next 100 degree increase to $1200{ }^{\circ} \mathrm{C}$ the slag underwent another mass loss. (Figure 3-13). The overall mass loss was $~ 2.1 \mathrm{wt} \%$. 


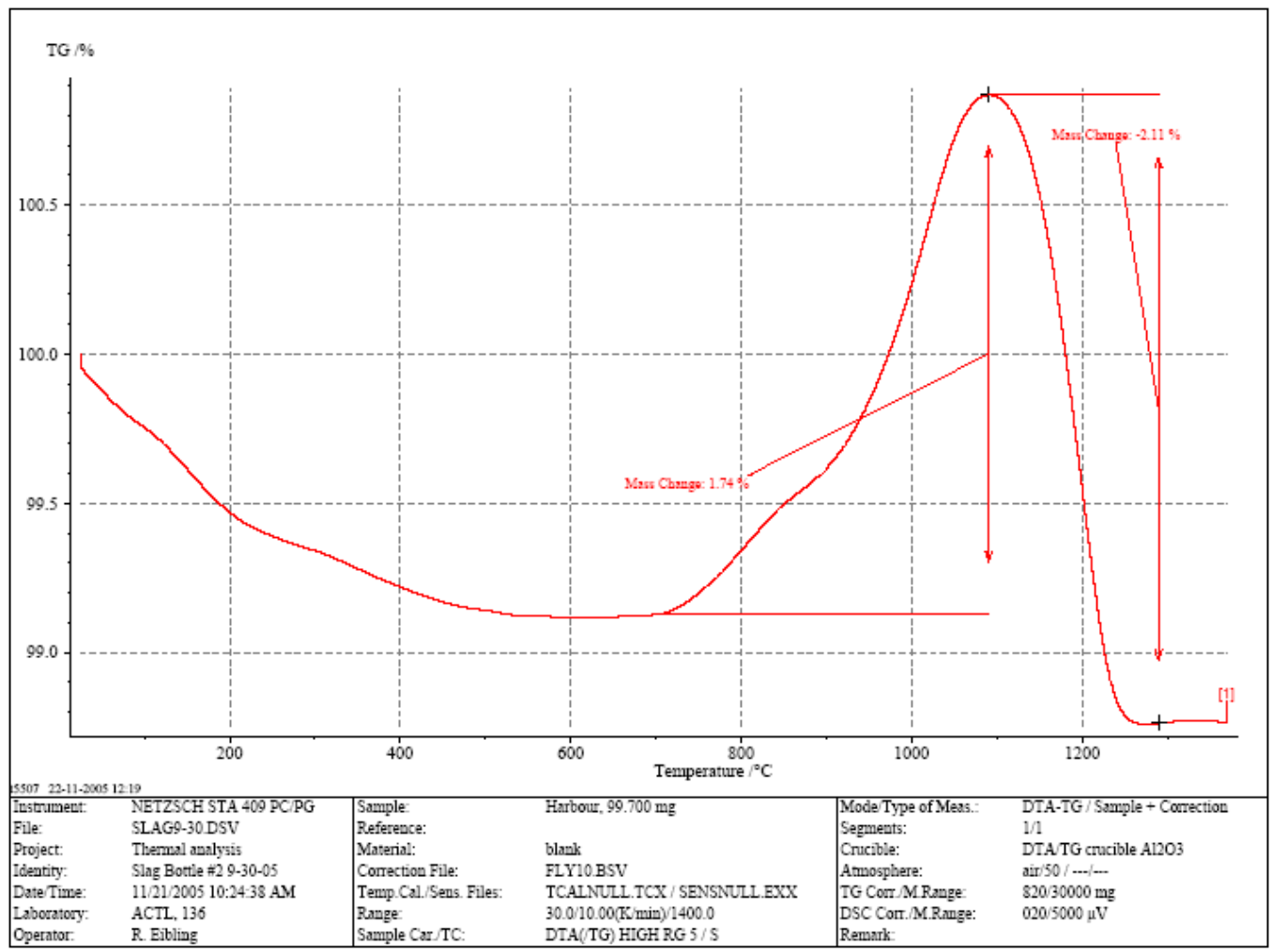

Figure 3-13 The TGA curve for Batch 2 ground granulated blast furnace slag.

Fly ash is of particular interest from a mass loss perspective due to the fact that carbon is composited with the fly ash during its formation in the coal burning power plants. Class F fly ash has a limit of $3 \mathrm{wt} \%$ moisture content and a maximum $6 \mathrm{wt} \%$ loss on ignition (LOI). This latter requirement encompasses the amount of carbon that is allowed with Class F flay ash.

Figure 3-14 shows the TGA spectrum for fly ash obtained from Batch 2. The overall loss of only $\sim 1.4 \mathrm{wt} \%$ readily meets the requirements of Class F fly ash. The differential thermal analysis curve is also shown in Figure 3-12 in blue.

The TGA spectrum for Batch 1 was run twice and was quite reproducible. Overall the loss was $\sim 3.0 \%$ with a contribution associated with carbon between 400 to $800{ }^{\circ} \mathrm{C}$ of $\sim 2.5 \%$. In contrast, the loss associated with carbon from Batch 2 was $~ 1.4 \%$. 


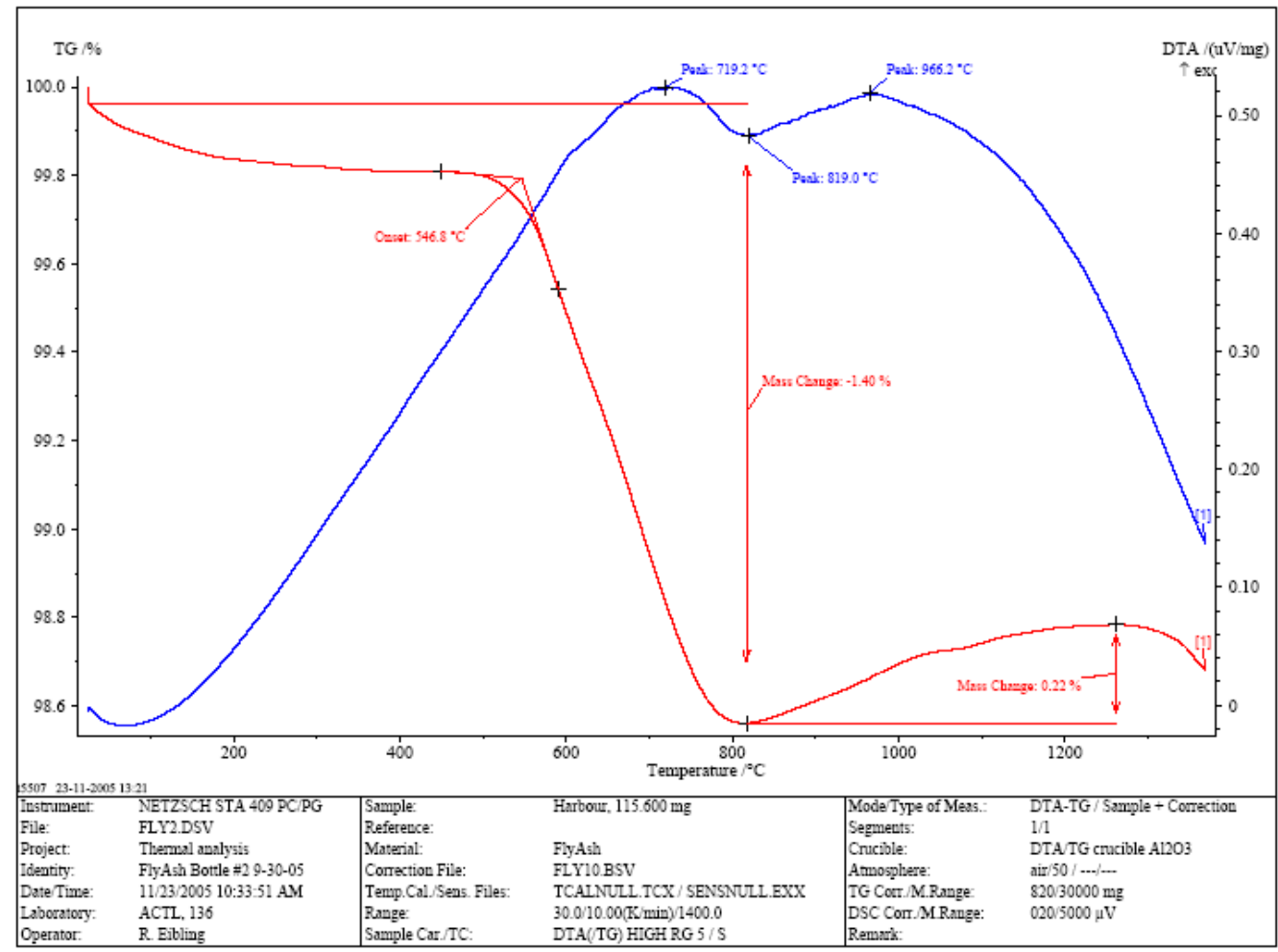

Figure 3-14 The TGA curve for Batch 2 fly ash.

\subsection{Slurry Rheology of Individual Premix Materials}

Slurry flowability is an important property of fresh Saltstone mixes. This flowability, as reflected in rheological parameters, depends on each of the binder (premix) materials added to the waste stream. For example, the yield stress and plastic viscosity of the slurry (at a fixed temperature) produced by adding blast furnace slag to the salt waste stream are dependent on the amount of slag added and on the slag's physical and chemical properties.

An approach was taken to characterize the slag, cement and fly ash by measuring the rheological properties (yield stress and plastic viscosity) of each binder material separately after its introduction into a well-defined salt simulant. This approach provides unique information for each binder and a method to track changes in the batches of binder materials as new batches are received at Saltstone.

For this characterization method, the modular caustic side solvent extraction unit (MCU) simulant [4] was chosen as the simulated salt waste stream. Each of the binders was tested separately with water to binder ratio of 0.60 for slag and cement and 0.50 for fly ash. The results are provided in Table 3.6. 
Table 3-6 Rheological data for slurries of fly ash, slag and cement in the MCU simulant

\begin{tabular}{||c|c|c|c|c||}
\hline \hline \multirow{2}{*}{ Material } & $\begin{array}{c}\text { Mixer Speed } \\
(\mathrm{RPM})\end{array}$ & \multirow{2}{*}{ Batch \# } & \multicolumn{2}{|c|}{ Bingham Plastic Rheological Properties } \\
\cline { 4 - 5 } & & & Yield Stress (Pa) & Plastic Viscosity (cP) \\
\hline \multirow{2}{*}{ Fly Ash } & Not Measured & 1 & Not Measured & Not Measured \\
\cline { 2 - 5 } & 460 & 2 & 0.1 & 62.2 \\
\hline \multirow{2}{*}{ Slag } & 410 & 1 & 5.6 & 66.7 \\
\cline { 2 - 5 } & 490 & 2 & 7.7 & 68.9 \\
\hline \multirow{2}{*}{ Portland Cement } & 950 & 1 & 19.2 & 124.6 \\
\cline { 2 - 5 } & 820 & 2 & 11.5 & 90.2 \\
\hline
\end{tabular}

The major change in rheological behavior between Batch 1 and 2 materials (excluding fly ash for which only a very limited amount of Batch 1 material remains) was observed for the portland cement. Batch 2 portland cement slurry shows a significantly lower yield stress and plastic viscosity than the Batch 1 portland cement slurry. This is consistent with batches made during the scoping study for the Saltstone variability study using all three premix materials (45\%/45\%/10\%) which showed a decrease in yield stress and plastic viscosity for Batch 2 based mixes versus Batch 1 based mixes with all other parameters equal (Table 3-7). Another interesting result in Table 3-6 is the fly ash, which has essentially no yield stress and can be considered a Newtonian fluid.

Table 3-7 Rheological data as a function of old (Batch 1) and new (Batch 2) binder materials using MCU simulant for a w/p ratio of 0.6

\begin{tabular}{||c|c|c|c|c|c||}
\hline \multirow{2}{*}{ Trail Run \# } & Fly Ash & Slag & $\begin{array}{c}\text { Portland } \\
\text { Cement }\end{array}$ & \multicolumn{2}{|c|}{ Bingham Plastic Rheological Properties } \\
\cline { 2 - 6 } & Batch \# & Batch \# & Batch \# & Yield Stress (Pa) & $\begin{array}{c}\text { Plastic Viscosity } \\
\text { (cP) }\end{array}$ \\
\hline 118 & 1 & 1 & 1 & 3.7 & 47.1 \\
\hline 119 & 2 & 2 & 2 & 2.7 & 36.8 \\
\hline 126 & 2 & 1 & 1 & 3.4 & 43.1 \\
\hline 127 & 2 & 1 & 2 & 2.5 & 37.0 \\
\hline 128 & 2 & 2 & 1 & 3.6 & 43.2 \\
\hline 129 & 2 & 1 & 1 & 3.8 & 38.0 \\
\hline 132 & 2 & 2 & 2 & 2.9 & 47.3 \\
\hline 133 & 2 & 1 & 2 & 2.9 & 35.5 \\
\hline 134 & 2 & 2 & 1 & 3.7 & 39.3 \\
\hline 161 & 2 & 2 & 2 & 2.6 & 50.4 \\
\hline 202 & 1 & 2 & 2 & 3.0 & 4.2 \\
\hline 203 & 1 & 2 & 1 & & \\
\hline
\end{tabular}




\subsection{DISCUSSION}

Additional Measurement Techniques. The properties of fly ash, slag and cement presented in Section 3.0 of this report comprise an overall and relatively broad baseline from which comparisons to future batches can be made. There are however, additional characterization techniques which could also provide useful properties to more completely characterize the powders. At this stage, the approach is to move forward with the current suite of tests, and depending on results from future batches, add additional testing when and if it is required. An example of an additional testing method is X-ray diffraction (XRD), which in this case would measure the degree of crystallinity in the slag and fly ash. Slag and fly ash are glass phase materials, which are produced by rapid cooling with only a very small amount of mineral phases. The XRD technique can quantify the percentage of crystallinity in slag and fly ash. Another example is wet sieving of particles. The procurement specifications, which in turn reference ASTM standards, require a minimum amount of fines above the 45 micron level by wet sieving for slag and fly ash. This testing was excluded at this point because the particle size distributions of slurries were already measured by laser light scattering and by dry sieving.

Reference Fresh and Cured Grout Properties. For this study, the underlying concern for Saltstone production is the extent to which variations in the properties of fly ash, slag and cement affect the fresh and cured properties of Saltstone. Therefore, as an integral part of this approach when new batches of premix materials are received, slurries of grout will be produced to a fixed recipe for several different simulant waste streams (Deliquification, Dissolution and Adjustment (DDA) and MCU and selected fresh and cured properties measured. This will provide a first indication if the new batches of premix materials significantly change the fresh or cured properties of the grout. The initial report on the Variability Study [2] with grout provides these reference recipes, the corresponding properties and the measurement uncertainties.

During the course of this study, two batches of fly ash, slag and portland cement were received and tested. For a fixed recipe, substitution of Batch 2 materials for Batch 1 materials increased the bleed water, decreased the yield stress and plastic viscosity, and increased the gel times. Further analysis of these materials demonstrated that it was the new batch of portland cement that was causing these changes.

\section{Compliance with the Procurement Specifications.}

At the time of writing this report, the procurement specifications for fly ash, slag and portland cement are in the process of being revised. Based on the latest draft revision for these specifications, the results of this Characterization Study can be used to determine, in those cases where the techniques are appropriate, whether or not the Batch 1 and 2 materials comply with the procurement specifications. 


\section{Class F Flay Ash:}

The procurement specifications require compliance with ASTM C-618-00 Specification which includes: $\mathrm{SiO}_{2}+\mathrm{Al}_{2} \mathrm{O}_{3}+\mathrm{Fe}_{2} \mathrm{O}_{3}>70$ wt \%; $\mathrm{SO}_{3}<5.0$ wt \%; Moisture content < 3 wt \%; Loss on Ignition < $6 \mathrm{wt} \%$; and Fineness $<34 \%$ retained on 45 micron sieve by wet sieving. The sum of silica, alumina and iron oxide readily meet the $>70 \mathrm{wt} \%$ requirement and the sulfur oxide meets the $<5.0 \mathrm{wt} \%$ requirement from analyses performed by the Process Science Analytical Laboratory on both batches of materials. The TGA results show compliance of the fly ash with the moisture content and loss on ignition requirements. The dry sieving gave the same results for the amount retained on the 45 micron sieve for both batches of $35.8 \mathrm{wt} \%$. The laser light scattering results on a slurry of fly ash in water showed retention of $35.9 \%$ by Batch 1 fly ash and $34.7 \%$ by Batch 2 fly ash. These results indicate that the fly ash batches may be marginally non-compliant with the wet sieving requirement of $<34 \%$ retained on the 45 micron sieve for both of these batches.

\section{Slag}

The procurement specifications require compliance with ASTM C-989-99 and allow for either Grade 100 or 120 ground iron blast furnace slag. The use of grade 120 can increase the heat of hydration, and therefore, this specification should be reconsidered in light of the organic volatility of some of the batches and corresponding temperature placement requirements. The sulfur content in the ASTM specification is $2.5 \%$ elemental and has been further reduced by the procurement specification to a maximum of $0.5 \%$ elemental sulfur. The elemental analyses performed by the Process Science Analytical Laboratory show 0.32 \% for Batch 1 and $0.83 \%$ for Batch 2 elemental sulfur. These results show that Batch 2 slag does not comply with the specifications. The fines specification requires that $<20 \mathrm{wt} \%$ of the material is retained by the 45 micron sieve during wet sieving. The laser light scattering results on slurries of the slag particles showed that $0.3 \mathrm{wt} \%$ of the Batch 1 slag and $0.0 \mathrm{wt} \%$ of the Batch 2 slag were greater than 45 microns in diameter. The dry sieving results showed greater retention, but as discussed with both slag and portland cement, these powders tended to aggregate during the dry sieving process and are therefore not representative of the actual particle size distribution.

\section{Portland Cement}

The procurement specifications require Type II portland cement and compliance with ASTM C150-00. Specifications include $\mathrm{SiO}_{2}>20$ wt \%; $\mathrm{Al}_{2} \mathrm{O}_{3}<6.0$ wt \%; $\mathrm{MgO}<6.0$ wt \%; $\mathrm{Fe}_{2} \mathrm{O}_{3}<$ $6.0 \mathrm{wt} \%$; and $\mathrm{SO}_{3}<3.0 \mathrm{wt} \%$. Table 3.5 of this report shows that all of the requirements are met by both batches of portland cement. The fineness requirement for portland cement is a surface area $>280 \mathrm{~m}^{2} / \mathrm{kg}$. No direct surface area measurements were performed as part of this study. However, the laser light scattering results calculate a surface area assuming spherical particles. Although the portland cement particles are not spherical, the calculated value for Batch 2 portland cement was $430 \mathrm{~m}^{2} / \mathrm{kg}$. 


\subsection{CONCLUSIONS}

Batch-to-batch variability in the chemical and physical properties of the fly ash, slag and portland cement (binders) will be an ongoing concern over the many years that salt waste from Tank 50 will be processed into grout at the Saltstone Processing Facility. This batch-to-batch variability in the properties of the binder materials translates to variability in the fresh and cured properties of Saltstone. Therefore, it is important to quantify the batch-to-batch variability of the binder materials and the resultant variation in grout properties. This report is the starting point for that process by providing the baseline (reference point) binder properties to which future batches of binder materials can be compared.

For this characterization effort, properties of fly ash, slag and portland cement were obtained and documented in this report. These properties included particle size distribution by laser light scattering and dry sieving, particle size and morphology by scanning electron microscopy, densities, chemical composition, rheological properties slurries made from individual binder material, and volatility through thermogravimetric analysis and differential thermal analysis.

The properties presented in this report also provide a baseline data set to assist in problem solving efforts when or if unanticipated and/or unwanted events occur at the Saltstone Processing Facility. 


\subsection{REFERENCES}

1. Scoping Studies for Development of Saltstone Variability Study, Technical Task Request, A. V. Staub, HLW/SSR/TTR-2005-0001, Rev. 0, March 2005.

2. Variability Study for Saltstone, J. R. Harbour, T. B. Edwards, E. K. Hansen and V. J. Williams, WSRC-TR-2005-00447, Rev. 0, October 2005.

3. Physical Characterization of FY2004 Saltstone Simulant Slurries, E. K. Hansen and C. A. Langton, WSRC-TR-2005-00365, August 2005.

4. Chemical Concentrations in Salt Solution Feed to the Saltstone Production Facility from DDA and ARP/MCU Batches, M. D. Drumm, M. A. Rios-Armstrong, and P. D d'Entremont, CBUPIT-2005-00095, April, 2005.

5. Cement Chemistry, H. F. W. Taylor, $2^{\text {nd }}$ Edition, Thomas Telford, London, August 1997. 


\section{Distribution:}

\begin{tabular}{lll} 
J.E. & Marra & SRNL \\
R.E. & Edwards & SRNL \\
D.A. & Crowley, & SRNL \\
T.B. & Calloway & 999-W \\
R.C. & Tuckfield & 773-42A \\
C.C. & Herman & $999-\mathrm{W}$ \\
F.M. & Pennebaker & SRNL \\
A.D. & Cozzi, & $999-\mathrm{W}$ \\
C.A. & Langton, & $773-43 \mathrm{~A}$ \\
T.L. & Fellinger & SRNL \\
J.P. & Vaughan & $773-41 \mathrm{~A}$ \\
M.F. & Williams & $999-1 \mathrm{~W}$ \\
M.S. & Miller & $704-\mathrm{S}$ \\
J.E. & Occhipinti & $704-\mathrm{S}$ \\
A.V. & Staub & $704-27 \mathrm{~S}$ \\
D.G. & Thompson & $704-\mathrm{Z}$ \\
T.E. & Chandler & $704-\mathrm{Z}$ \\
P.D. & Schneider & $704-\mathrm{Z}$ \\
M. A. & Rios-Armstrong & $766-\mathrm{H}$ \\
\hline
\end{tabular}

